\title{
EKSTRAKSI DAN KARAKTERISASI INULIN DARI UMBI DAHLIA (Dahlia sp.L) SEGAR DAN DISIMPAN
}

\author{
Hevi Horiza ${ }^{1}$, Minda Azhar ${ }^{2}$, Jon Efendi ${ }^{2}$ \\ ${ }^{1}$ Jurusan Kesehatan Lingkungan Poltekkes Kemenkes Tanjungpinang \\ ${ }^{2}$ Laboratorium Kimia FMIPA Universitas Negeri Padang, \\ e-mail: hevi220987@gmail.com, minda@fmipa.unp.ac.id, khalidsefendi@gmail.com
}

\begin{abstract}
Inulin is a natural polymer composed of monomers fructose, which is connected with the linear bonding $\beta$-2,1-fruktosil-fructose. One source of inulin is the dahlia tubers $(65.700 \%)$. The purpose of this study was to determine the water content, degree of purity inulin and how the value of the degree of polymerization inulin from dahlia tubers fresh and stored 4 weeks kinds of decorative strands formal crimson crown. This research was conducted experiments in Chemistry Research Laboratory UNP. The object of research was a kind of decorative dahlia tubers formal crimson obtained in the area of Aia Tawa, Kampung Batu nature, Solok. Inulin was characterized by using GC (Gas Chromatograpy) and HPLC(High-PerformanceLiquidChromtography). Determination of water content by using method of the AOAC(Associationof Official of Analytical Chemist).The results showed that the water content of dry weight percent (bk) inulin from dahlia tubers fresh is $2.123 \%$, Inui figure is not much different than the inulin from dahlia tubers stored 4 weeks $2.003 \%$. Based on the GC spectrum can be analyzed qualitatively that inulin extracted from dahlia tubers have a degree of polymerization of smaller than commercialinulin. Chicory Based on the spectrum of HPLC showed that inulin extracted from the tubers of dahlias has a purity level is almost the same as inulin commercial Chicory merck Fluka.
\end{abstract}

Keywords: Extraction, Characterization, Inulin, Dahlia Tuber

\section{PENDAHULUAN}

Bunga dahlia adalah bunga indah yang memiliki beberapa warna mulai dari warna putih, merah, ungu, kuning, jingga, sampai kombinasi beberapa warna. Umbi tanaman dahlia memiliki potensi untuk dikembangkan sebagai bahan utama dalam pembuatan sirup fruktosa karena umbinya mengandung inulin yang tinggi yaitu sekitar
65,70\% berat kering (Rukmana,2000: 11). Inulin merupakan polimer alami yang terdiri dari monomer-monomer fruktosa. Monomer-monomer tersebut dihubungkan dengan ikatan linier $\beta$-2,1-fruktosil-fruktosa. Pada ujung terminal polimer inulin dapat terikat glukosa dengan ikatan $\alpha-1,2$ (Franck, 2003:443).

Inulin dapat dihidrolisis menjadi monomernya yaitu fruktosa. Untuk 


\section{EKSAKTA Vol. 18 No.1 April 2017}

E-ISSN : 2549-7464, P-ISSN : 1411-3724

mengubah inulin menjadi monomermonomernya dapat dilakukan dengan cara menghidrolisisnya menggunakan katalis asam seperti asam klorida, asam sitrat, asam oksalat dan katalis enzim yaitu inulinase. Untuk produksi sirup fruktosa sebaiknya digunakan inulin dengan derajat polimerisasi yang kecil, agar proses hidrolisis dapat berlangsung cepat.

Selain itu, inulin dapat digunakan sebagai prebiotik. Prebiotik adalah suplemen makanan yang berfungsi sebagai substrat mikroflora usus. Inulin merupakan suatu makanan yang lebih disukai oleh colonic microflora dan dapat meningkatkan keseimbangan bakteri baik dalam usus (Roberfroid,1993).

Penelitian mengenai inulin yang telah dilakukan diantaranya ekstraksi, karakterisasi dan kajian potensi inulin dari umbi dahlia (Dahlia pinnata L.). Hasil penelitian yang diperoleh untuk umbi yang mempunyai kadar inulin tertinggi adalah umbi dahlia jenis pompon dengan helaian mahkota berwarna jingga yaitu sebesar $82,8 \%$ berat kering. Rendemen terbaik adalah $4,4 \%$ dihasilkan dari umbi dahlia jenis pompon dengan helaian mahkota berwarna merah darah. Inulin murni yang tereksraksi paling banyak sebesar $41,7 \%$ berat kering dari seluruh inulin yang terdapat di dalam umbi dihasilkan oleh umbi dahlia jenis formal decorative berwarna ungu muda. Jenis umbi dahlia yang paling berpotensi digunakan sebagai sumber prebiotik adalah umbi dahlia jenis pompon dengan helaian mahkota berwarna merah darah (Widowati,2005).

Penelitian tentang karakaterisasi inulin telah dilakukan pada tanaman chicory yang berasal dari Portugal. Karakterisasi ekstrak inulin digunakan HPLC. Hasilnya menunjukkan bahwa kandungan gula bebas dan sukrosanya sangat rendah, dan untuk membentuk inulin (DP>2) disusun dari 94\% fruktosa dan 6\% glukosa (Costa, 2005). Penentuan derajat polimerisasi inulin dari Jerussalem artichoke diperoleh bahwa fraksi derajat polimerisasi (DP) 3-10 naik, fraksi DP $>10$ turun setelah 4-6 minggu penyimpanan umbi Jerusalem artichoke (Helianthus tuberosus L.) (Saengthongpinit, 2005).

Pada artikel ini dilaporkan kadar air inulin, kemurnian inulin dan derajat polimerisasi inulin yang diekstrak dari umbi tanaman dahlia (Dahlia spp. L) segar dan disimpan. Tanaman dahlia yang digunakan adalah jenis decorative formal yang helaian mahkota berwarna merah tua. Sebagai pembanding digunakan inulin dari chicory.

\section{METODE}

Penelitian ini merupakan penelitian eksperimen. Ekstraksi inulin dilakukan di Laboratorium Penelitian, dan Laboratorium Biokimia FMIPA Universitas Negeri Padang. Karakterisasi inulin dengan GC dilakukan di Laboratorium Pestisida, Holtikultura Padang. Karakterisasi inulin dengan HPLC dilakukan di Laboratorium Farmasi, Fakultas Farmasi Universitas Andalas.

Objek penelitian adalah inulin yang diekstraksi dari umbi Dahlia (Dahlia sp.L) yang tumbuh di daerah Aia tawa, Kampung Batu Dalam, Kecamatan Danau Kembar, Kabupaten Solok, Sumatera Barat.

Alat-alat yang digunakan adalah blender, alat-alat gelas, lemari es, neraca teknis dan neraca analitis, sentrifugasi, corong bouchner, alat vakum, oven, termometer, penangas air, GC, HPLC.

Bahan-bahan yang digunakan adalah umbi dahlia, etanol, $\mathrm{HCl}$ p.a dan resorsinol, aquades, metanol absolut, aquabidest, inulin chicory. 


\section{EKSAKTA Vol. 18 No.1 April 2017}

E-ISSN : 2549-7464, P-ISSN : 1411-3724

1. Ekstraksi inulin

Ekstraksi inulin dari umbi dahlia segar dan umbi dahlia yang didiamkan 3 minggu dilakukan sesuai dengan prosedur yang telah dilakukan oleh Andayani, 2001.Umbi dahlia dikuliti, dibersihkan dan dipotong kecil. Potongan umbi dahlia ditimbang sebanyak 500 gram, kemudian ditambahkan $1 \mathrm{~L}$ aquades dan diblender hingga membentuk jus umbi dahlia. Jus umbi dahlia dipanaskan pada suhu $80-90^{\circ} \mathrm{C}$ selama 30 menit, kemudian disaring sehingga diperoleh filtrat dan residu. Filtrat dan residu diuji secara kualitatif dengan reagen seliwanoff. Uji postif ditandai dengan pembentukan warna merah dengan cepat yang menunjukkan bahwa filtrat mengandung gula ketosa. Filtrat ditambahkan etanol $30 \%$ dan disimpan dalam freezer $\left( \pm-10^{\circ} \mathrm{C}\right)$ selama 18 jam, kemudian pada suhu kamar selama 2 jam. Filtrat tersebut selanjutnya disentrifugasi pada $9000 \mathrm{rpm}$ selama 10 menit sehingga diperoleh endapan inulin basah 1 dan supernatan 1 . Uji kualitatif dilakukan dengan reagen seliwanoff terhadap endapan inulin basah dan supernatan. Supernatan 1 ditambahkan etanol $30 \%$ dan disimpan dalam freezer $( \pm$ $10^{\circ} \mathrm{C}$ ) selama $18 \mathrm{jam}$. Kemudian didiamkan pada suhu kamar selama 2 jam dan dilanjutkan dengan sentrifugasi pada 9000 rpm selama 10 menit sehingga diperoleh endapan inulin basah 2 dan supernatan 2 . Uji kualitatif dengan reagen seliwanoff dilakukan pada endapan inulin basah 2 dan supernatan 2. Supernatan 2 ditambahkan etanol $30 \%$ dan disimpan dalam freezer $( \pm-$ $10^{\circ} \mathrm{C}$ ) selama 18 jam. Campuran ini didiamkan pada suhu ruang selama 2 jam, kemudian disentrifugasi pada $9000 \mathrm{rpm}$ selama 10 menit sehingga diperoleh endapan inulin basah 3 dan supernatan 3 . Uji kualitatif positif terhadap endapan inulin basah 3 dan sedikit positif terhadap supernatan 3 sehingga penambahan etanol $30 \%$ pada supernatan 3 tidak dilakukan. Ketiga endapan inulin basah $(1,2,3)$ dicampurkan dan diperoleh massa total.

Inulin basah ditambahkan aquades 40 $\mathrm{mL}$ dan karbon aktif 0,2 g. Campuran ini dipanaskan pada suhu $80-90^{\circ} \mathrm{C}$ selama 30 menit. Selanjutnya larutan disaring dengan penyaring Buchner dengan bantuan alat vakum sehingga diperoleh filtrat bening. Selanjutnya filtrat sebanyak $70 \mathrm{~mL}$ ditambahkan $28 \mathrm{~mL}$ etanol $30 \%$ dan disimpan di dalam freezer $\left( \pm-10^{\circ} \mathrm{C}\right)$ selama 18 jam. Filtrat tersebut didiamkan pada suhu ruang selama 2 jam, selanjutnya disentrifugasi pada $9000 \mathrm{rpm}$ selama 10 menit sehingga diperoleh endapan putih dan supernatan bening. Endapan putih tersebut dikeringkan dalam oven suhu $50-60^{\circ} \mathrm{C}$ selama 10 jam sehingga diperoleh inulin kering.

\section{Penentuan Kadar Air}

Kadar air inulin ditentukan sesuai metoda pada AOAC (Association of Official of Analytical Chemist). Inulin dipanaskan pada suhu $100^{\circ} \mathrm{C}$ dengan cawan penguap berulang-ulang sampai beratnya konstan. Inulin yang diekstrak dari umbi dahlia segar dilakukan 13 kali pengovenan, sedangkan inulin yang diekstrak dari umbi dahlia disimpan 4 minggu dilakukan 10 kali pengovenan

\section{Karakterisasi}

Karakterisasi yang dilakukan dalam penelitian ini adalah penentuan kemurnian inulin menggunakan HPLC tipe SCL-10A vp, SPD-10A vp, LC-10AT vp. Fasa stasioner yang digunakan adalah silika. Fasa gerak yang digunakan etanol $30 \%$. Detektor yang digunakan adalah UV pada panjang gelombang $210 \mathrm{~nm}$. Kecepatan alir eluen adalah $1 \mathrm{~mL} / \mathrm{menit}$. Inulin sebanyak 0,001 


\section{EKSAKTA Vol. 18 No.1 April 2017}

E-ISSN : 2549-7464, P-ISSN : 1411-3724

gram dilarutkan dalam $10 \mathrm{~mL}$ etanol $30 \%$. Larutan inulin tersebut disonifikasi selama 30 menit untuk melepaskan gas. Setelah itu larutan inulin disaring dengan kertas saring wathman $0,2 \mu \mathrm{m}$, kemudian $80 \mu \mathrm{L}$ larutan inulin tersebut diinjeksikan ke kolom. Sebagai standar digunakan inulin chicory. Waktu retensi inulin dari umbi dahlia dibandingkan dengan waktu retensi inulin chicory.

Derajat polimerisasi inulin ditentukan secara kualitatif menggunakan GC tipe 2010. Jenis kolom yang digunakan adalah Rtx-5 dengan panjang 30 meter dan diameter $0,25 \mathrm{~mm}$. Fasa diam yang digunakan Crossbond-5\% diphenyl-95\% dimethylpolysiloxane. Gas pembawa adalah $\mathrm{N}_{2}$, dengan detektor FID (Flame Ionisation Detector). Suhu maksimumnya $350^{\circ} \mathrm{C}$. Inulin sebanyak 0,001 gram dilarutkan dalam etanol $30 \%$, selanjutnya diinjeksikan ke kolom GC menggunakan pipet mikro. Sebagai standar digunakan inulin chicory. Waktu retensi inulin dahlia dibandingkan dengan inulin chicory.

\section{HASIL DAN PEMBAHASAN}

Pembahasan penelitian ini dikelompokkan empat yaitu ekstraksi inulin, kadar air inulin, derajat polimerisasi inulin dengan menggunakan GC dan kemurnian inulin dengan menggunakan HPLC.

\section{a. Ekstraksi Inulin}

Inulin diekstraksi dari umbi dahlia segar dan umbi dahlia disimpan 4 minggu. Inulin diekstraksi dari umbi dahlia sesuai metode yang digunakan Andayani (2001). Inulin basah yang diperoleh dari $500 \mathrm{~g}$ umbi dahlia segar yang telah dikuliti adalah 173,478 g. Inulin basah yang diperoleh dari $250 \mathrm{~g}$ umbi dahlia yang disimpan selama 4 minggu setelah dikuliti adalah 95,392 g. Angka ini menunjukkan bahwa mengekstrak inulin dari umbi dahlia segar maupun disimpan menghasilkan inulin basah yang hampir sama banyak.

Dalam proses pemucatan tidak semua inulin basah yang digunakan. Inulin basah yang diekstrak dari umbi dahlia segar digunakan $20 \mathrm{~g}$ inulin basah diperoleh inulin kering putih sebanyak 2,757 g. Untuk pemucatan inulin basah yang diekstrak dari umbi dahlia yang disimpan selama 4 minggu (28 hari) digunakan $10 \mathrm{~g}$, diperoleh inulin kering putih $1,379 \mathrm{~g}$.

Metoda ekstraksi inulin dari umbi dahlia didasarkan pada metode yang telah digunakan oleh Andayani (2001), dengan beberapa tahap yaitu tahap pengupasan, penghancuran, presipitasi dan pemucatan. Tujuan pengupasan adalah untuk membuang kulit yang tidak diperlukan. Penghancuran menggunakan blender bertujuan agar ekstraksi inulin oleh pelarut lebih efektif, semakin banyak inulin yang terekstrak sehingga rendemen hasil inulin semakin tinggi.

Proses ekstraksi inulin dilakukan melalui presipitasi dan pemucatan inulin basah. Inulin yang telah diperoleh dari proses presipitasi yang dilakukan dengan penambahan etanol 30\% sebanyak $40 \%$ $(\mathrm{v} / \mathrm{v})$. Pada proses pemisahan inulin basah dari pelarutnya digunakan alat sentrifugasi untuk mengurangi kehilangan inulin yang dapat terbuang akibat presipitasi yang tidak sempurna. Proses sentrifugasi dilakukan untuk meminimalisasi kandungan pelarut pada inulin basah, sehingga proses pengeringan dapat berjalan cepat.

Proses pemucatan bertujuan untuk mendapatkan inulin yang berwarna putih. Proses pemucatan dilakukan dengan melarutkan inulin basah dalam aquades dengan perbandingan 1:2 (b/b) yang dipanaskan pada suhu $70-80^{\circ} \mathrm{C}$, lalu 


\section{EKSAKTA Vol. 18 No.1 April 2017}

E-ISSN : 2549-7464, P-ISSN : 1411-3724

penambahan arang aktif sebayak $1 \%(\mathrm{~b} / \mathrm{b})$. Penambahan arang aktif terhadap inulin basah, memberikan inulin yang berwarna putih (Gambar 1). Hal ini disebabkan karena zat warna yang merupakan bahan non inulin terikat pada arang aktif. Arang aktif memiliki sifat mampu menyerap zat warna secara efektif. Pemanasan pada suhu 70$80^{\circ} \mathrm{C}$ dapat menyebabkan protein pada ekstrak inulin terdenaturasi.

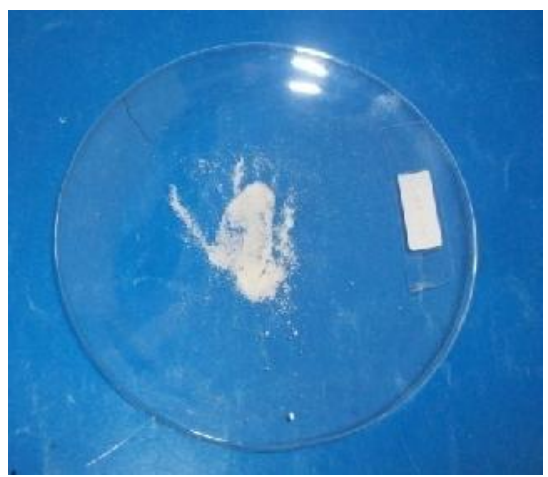

Gambar 1. Inulin

\section{b. Kadar Air Inulin}

Penentuan kadar air dilakukan berdasarkan metoda AOAC. Sampel inulin kering dipanaskan pada suhu $100^{\circ} \mathrm{C}$ dan ditimbang secara berulangkali sampai diperoleh berat konstan (Tabel 1). Inulin yang diekstrak dari umbi dahlia segar dibandingkan kadar airnya dengan inulin yang diekstrak dari umbi dahlia disimpan 4 minggu. Inulin yang diekstrak dari umbi dahlia segar dilakukan pengovenan 13 kali dengan waktu masing-masing 30 menit, agar diperoleh berat konstan. Inulin yang diekstrak dari umbi dahlia yang disimpan 4 minggu dilakukan pengovenan 10 kali masing-masing 30 menit untuk memperoleh berat konstan.
Tabel 3. Kadar Air Inulin

\begin{tabular}{|c|c|c|}
\hline No & Jenis inulin (waktu ektraksi) & $\begin{array}{c}\text { Kadar air } \\
\text { (bk) } \\
\%\end{array}$ \\
\hline 1 & $\begin{array}{llll}\text { Inulin segar (diekstrak } & 2 & \text { hari } \\
\text { setelah panen) }\end{array}$ & 2,123 \\
\hline 2 & $\begin{array}{l}\text { Inulin } 4 \text { minggu (diekstrak } 28 \text { hari } \\
\text { setelah panen) }\end{array}$ & 2,003 \\
\hline
\end{tabular}

Kadar air inulin yang diekstrak dari umbi dahlia segar adalah 2,123\%, Hal ini berarti inulin mempunyai kadar bahan kering 97,877\%. Kadar air inulin yang diekstrak dari umbi dahlia disimpan 4 minggu adalah 2,003\%. Ini berarti inulin mempunyai kadar bahan kering 97,997\%. Berdasarkan data kadar air yang diperoleh menunjukkan bahwa kadar air inulin yang diekstrak dari umbi dahlia disimpan lebih rendah dibandingkan dengan inulin yang diekstrak dari umbi dahlia segar. Pada penelitian yang dilakukan Andayani (2001) diperoleh kadar air 3,02\%.

\section{c. Derajat Polimerisasi Inulin dengan Menggunakan GC}

Berdasarkan spektrum GC, diperoleh dua puncak tajam pada waktu retensi 6,443 dan 6,878 menit untuk inulin chicory (Gambar 2a). Hal ini menunjukkan bahwa pada inulin chicory diperkirakan terdapat 2 jenis Derajat Polimerisasi (DP) yang berbeda. Pada spektrum GC inulin chicory juga terdapat dua puncak rendah pada waktu retensi 6,346 dan 7,082 menit. Hal ini menunjukkan bahwa terdapat inulin dengan DP rendah diperkirakan ada dalam jumlah kecil pada inulin chicory. Inulin yang diekstrak dari umbi dahlia segar diperoleh satu puncak rendah pada waktu retensi 4,205 menit dan satu puncak tajam pada waktu retensi 4,290 menit (Gambar 2b). Inulin yang diekstrak dari umbi dahlia yang disimpan selama 4 minggu diperoleh satu 


\section{EKSAKTA Vol. 18 No.1 April 2017}

E-ISSN : 2549-7464, P-ISSN : 1411-3724

puncak rendah pada waktu retensi 3,157 menit dan satu puncak tajam pada waktu retensi 3,226 menit (Gambar 2c). Berdasarkan waktu retensi yang diperoleh inulin yang diekstrak dari umbi dahlia segar mempunyai DP yang lebih kecil dibandingkan inulin chicory, tetapi mempunyai DP yang lebih besar dibandingkan inulin yang diekstrak dari umbi dahlia disimpan 4 minggu.

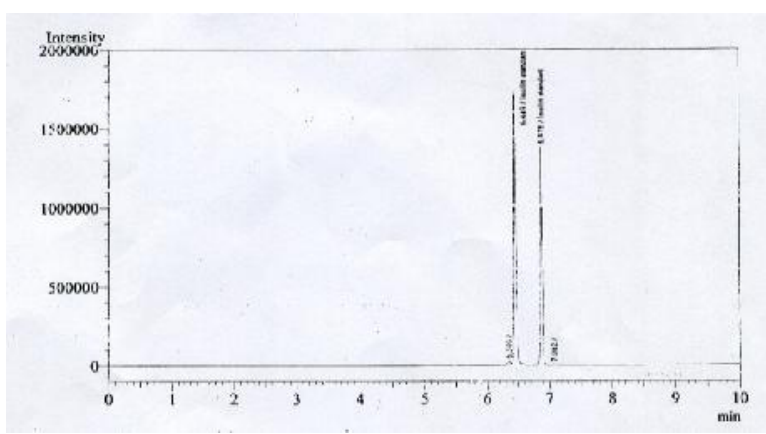

(a)

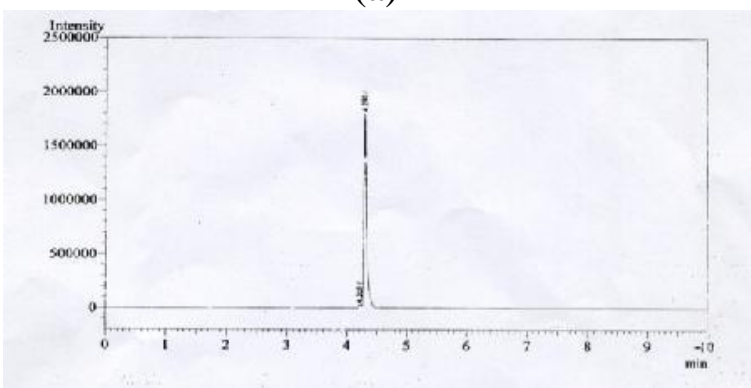

(b)

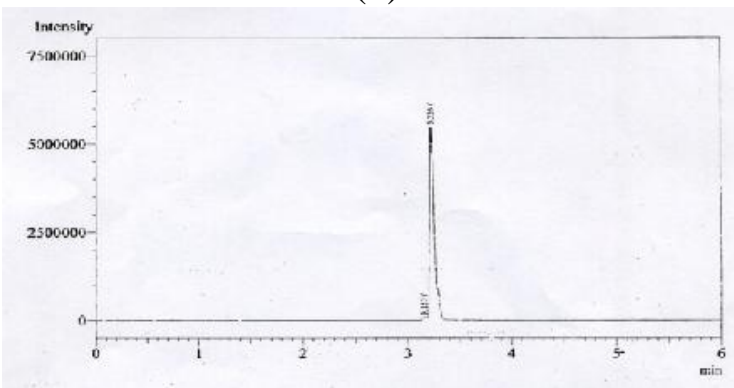

(c)

Gambar 2. Spektrum GC Inulin (a) inulin chicory (b) inulin dari umbi dahlia segar (c) inulin dari umbi dahlia disimpan 4 minggu
Jika dilihat dari tinggi puncak spektrum yang dihasilkan pada spektrum GC, inulin chicory mempunyai dua puncak tajam dengan tinggi 1723323 dan 1373033 . Inulin hasil ekstraksi dari umbi dahlia segar mempunyai satu puncak tajam dengan tinggi 1786677 dan inulin hasil ekstraksi dari umbi dahlia disimpan 4 minggu mempunyai satu puncak tajam dengan tinggi 5416747. Dari data ini dapat diperkirakan bahwa inulin dengan DP lebih kecil semakin banyak jumlahnya pada inulin hasil ektraksi dari umbi dahlia disimpan 4 minggu, jika dibandingkan dengan inulin komersial chicory dan inulin hasil ekstraksi dari umbi dahlia segar. Inulin dengan fraksi DP 3-10 naik, fraksi DP> 10 turun dengan penyimpanan umbi 4-6 minggu umbi Jerussalem arthicoke (Helianthus tuberosus L) (Saengthopinit, 2005:2). Semakin meninggkatnya jumlah molekul dengn DP kecil pada umbi dahlia yang disimpan 4 minggu disebabkan oleh aktivitas enzim inulinase.

\section{d. Kemurnian Inulin dengan} Menggunakan HPLC

Penentuan kemurnin inulin dilakukan dengan menggunakan HPLC di Laboratorium Farmasi Fisika, Fakultas Farmasi Universitas Andalas. Kemurnian inulin hasil ekstraksi dibandingkan dengan inulin chicory. Penentuan kemurnian inulin telah dilakukan sebelumnya oleh Andayani (2001), dari spektrum HPLC diperoleh waktu retensi 5,247 menit untuk inulin chicory, dan 5,212 menit untuk inulin yang diekstrak dari umbi dahlia. Waktu retensi yang diperoleh tidak terlalu berbeda antara inulin chicory dengan inulin dari umbi dahlia.

Analisis sampel inulin dilakukan pada kolom apolar C18 fasa terbalik, dengan detektor UV. Panjang gelombang yang digunakan untuk analisa inulin dengan fasa 


\section{EKSAKTA Vol. 18 No.1 April 2017}

E-ISSN : 2549-7464, P-ISSN : 1411-3724

gerak etanol $30 \%$ adalah $210 \mathrm{~nm}$. Kecepatan alir yang digunakan adalah 1,0 mL/menit. Dari spektrum HPLC puncak tajam dari inulin chicory muncul pada waktu retensi 2,733 menit (Gambar 3a). Untuk inulin dari umbi dahlia segar puncak tajam muncul pada waktu retensi 2,692 menit (Gambar 3b). Untuk inulin dari umbi dahlia yang disimpan selama 4 minggu puncak tajam muncul pada waktu retensi 2,683 menit (Gambar 3c). Berdasarkan data yang diperoleh tidak ada perbedaan yang signifikan pada waktu retensi inulin yang diekstrak dari umbi dahlia segar dengan inulin chicory dan inulin yang diekstrak dari umbi dahlia disimpan 4 minggu. Hal ini menunjukkan bahwa tingkat kemurnian inulin hasil ekstraksi dari umbi dahlia segar hampir sama dengan inulin chicory ataupun inulin yang diekstrak dari umbi dahlia disimpan 4 minggu.

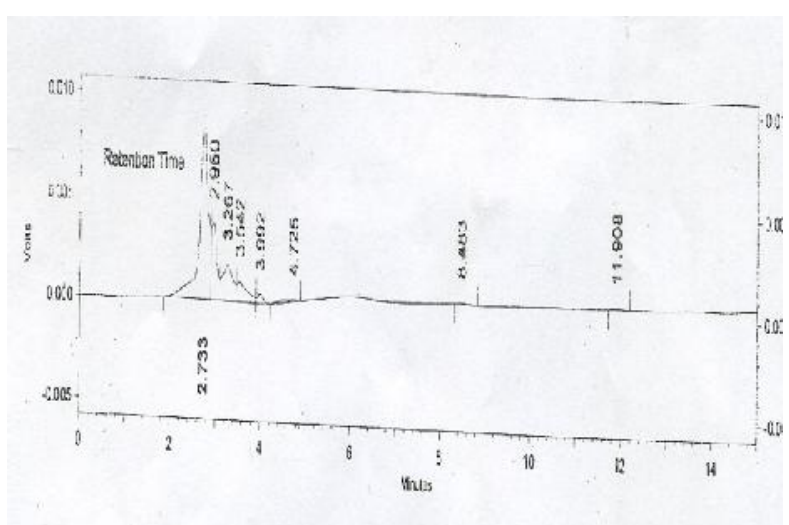

(a)

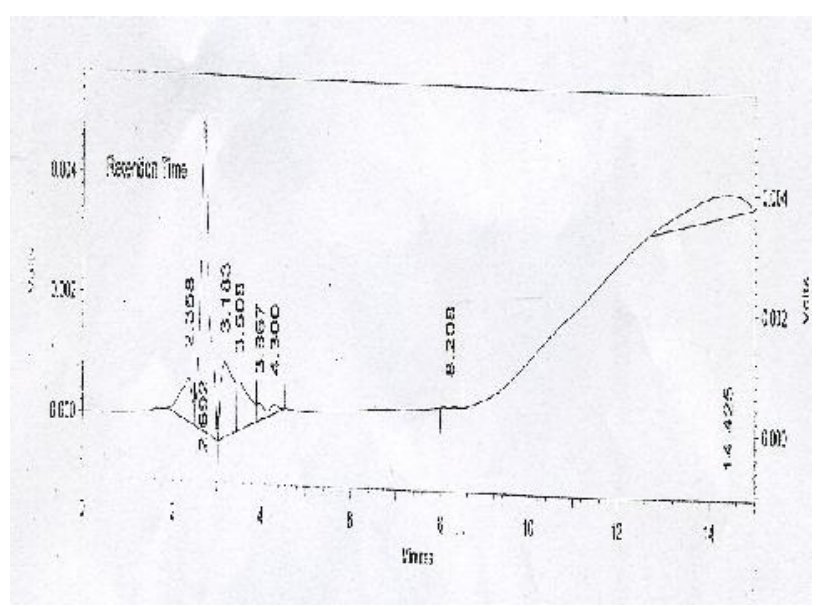

(b)

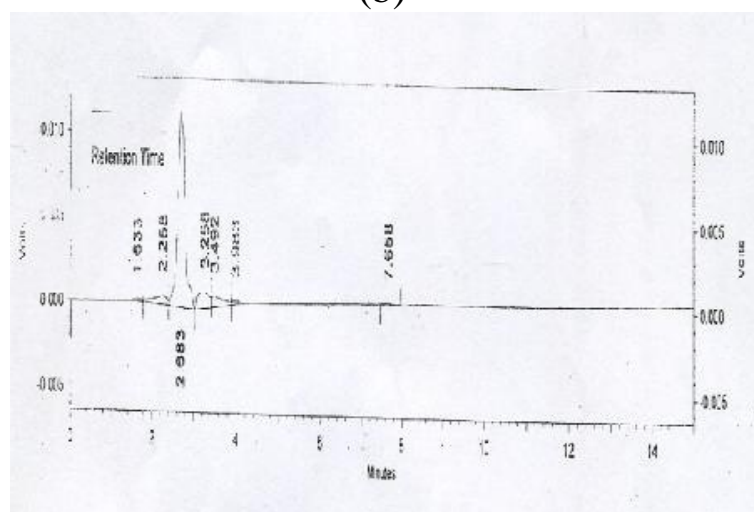

(c)

Gambar 3. Spektrum HPLC (a) inulin chicory (b) inulin dari umbi dahlia segar (c) inulin dari umbi dahlia disimpan 4 minggu

Kemurnian inulin hasil ekstraksi dari umbi dahlia hampir sama dengan inulin chicory disebabkan oleh proses presipitasi dan proses pemucatan inulin basah, sehingga kotoran seperti zat warna dan protein terserab pada arang aktif. Arang aktif memiliki sifat mampu menyerap zat warna secara efektif. Pemanasan pada suhu $\left(70-80^{\circ} \mathrm{C}\right)$ dapat menyebabkan protein terdenaturasi.

Jika dilihat dari tinggi puncak yang dihasilkan pada inulin chicory terdapat satu puncak tajam dengan tinggi 8965 atau $55,511 \%$ dari total puncak yang terdapat pada spektrum HPLC inulin chicory. Untuk 


\section{EKSAKTA Vol. 18 No.1 April 2017}

E-ISSN : 2549-7464, P-ISSN : 1411-3724

inulin yang diekstrak dari umbi dahlia segar terdapat satu puncak tajam dengan tinggi 5267 atau 59,147\% dari total puncak yang terdapat pada spektrum HPLC inulin hasil ekstraksi dari umbi dahlia segar.

Inulin yang diekstrak dari umbi dahlia disimpan 4 minggu terdapat satu puncak tajam dengan tinggi puncak 11529 atau $81,466 \%$ dari total puncak yang terdapat pada spektrum HPLC inulin hasil ekstraksi dari umbi dahlia disimpan 4 minggu. Hal ini juga menunjukkan bahwa inulin dengan DP kecil terdapat pada inulin yang diekstrak dari umbi dahlia segar, tetapi pada inulin yang diekstrak dari umbi dahlia disimpan 4 minggu DP kecil lebih dominan.

\section{KESIMPULAN}

Berdasarkan hasil dan pembahasan terhadap ekstraksi dan karakterisasi inulin dari umbi dahlia (Dahlia sp.L) segar dapat disimpulkan,

1. Kadar air inulin yang diekstrak dari umbi dahlia segar $(2,123 \%)$ lebih besar dibandingkan dengan inulin yang diekstrak dari umbi dahlia disimpan 4 minggu $(2,003 \%)$.

2. Berdasarkan data HPLC kemurnian inulin yang diekstrak dari umbi dahlia segar hampir sama dengan inulin chicory dan inulin yang diekstrak dari umbi dahlia disimpan 4 minggu.

3. Berdasarkan data GC diperoleh bahwa inulin dengan DP kecil terdapat pada inulin yang diekstrak dari umbi dahlia segar dibandingkan inulin chicory, tetapi DP kecil lebih banyak terdapat pada inulin yang diekstrak dari umbi dahlia disimpan 4 minggu.

\section{DAFTAR PUSTAKA}

Andayani, Nova fitria. 2001. Produksi Sirup Fruktosa dari Inulin Dahlia pinnata Cav. Secara Hidrolisis Asam. Skripsi. Bogor. Fakultas Teknologi Pertanian IPB.

Azhar, Minda. 2007. Aktivitas Enzim Inulinase Hasil Ekstraksi dengan Etanol dari Umbi Dahlia. SAINSTEK Vol. X. Nomor I, September 2007. Jurusan Kimia FMIPA Universitas Negeri Padang

Costa, Maria Luisa Berao-Da; Maria Isabel Nunes Januario; et al. 2005. Characterisation of inulin from chicory and Salsify cultivated in Portugal. Alim.Nutr.Araraquara. V.16, n.3, p.221-225, Jul/set. Departamento de Agro-Indústrias e Agronomia Tropical. Instituto Superior de Agronomia. Lisboa - Portugal.

Franck, Anne \& Leen De Leenheer. 2003. Inulin. e-mail:anne.franck@ orafti.com.

Roberfroid, Marcel. 2005. Inulin-Type Fructans Functional Food Ingredients. New York: CRC Press LLC

Rukmana, Rahmat.2000. Dahlia. Jakarta: Kanisius.

Saengthongpinit, Wanpen. 2005. Influence of Harvest Time and Storage Temperature on Characteristics of Inulin from Jerusalem artichoke (Helianthus tuberosus L.) Tubers. Postharvest Biology and Technology. Volume 37, Issue 1, July 2005. Departement of Food Science and Technology, Faculty of Agro-Industry, Kasetsart University, Chatuchak, Bangkok. Thailand 


\section{EKSAKTA Vol. 18 No.1 April 2017}

E-ISSN : 2549-7464, P-ISSN : 1411-3724

Widowati, Sri dkk. 2005. Ekstraksi, Karakterisasi, dan Kajian Potensi Prebiotik Inulin dari Umbi dahlia (Dahlia pinata L). Makalah Disajikan dalam Seminar Rutin Puslitbang Tanaman Pangan, Bogor, 16 Juni 2005.

Yildiz, Sibel dan N. Suzan Kincal. 2007. HPLC Analysis For Determination of Characteristics of FructoOligosaccharide Syrups Extracted from Jerusalem artichoke. SD FEN EDEBÍYAT FAK LTESÍ. FEN DERGÍSí (E-DERGí), 2 (1), 92-103 